\title{
Daily Soy-Catfish-Anchovy-Rice (SCAR) Porridge Increases 25(OH)D Serum Levels in Tuberculosis Patients with Vitamin D Receptor Gene Polymorphisms
}

\author{
Dina Keumala Sari ${ }^{1, *}$, Ridha Dharmajaya ${ }^{2}$, Mutiara Indah Sari ${ }^{3}$, Dewi Masyithah Darlan ${ }^{4}$ \\ ${ }^{1}$ Tropical Medicine Study Program, Faculty of Medicine, Universitas Sumatera Utara, Jl. Dr. Mansyur No.5, Medan 20155, Indonesia \\ ${ }^{2}$ Neurosurgery Department, Faculty of Medicine, Universitas Sumatera Utara, Jl. Dr. Mansyur No.5, Medan 20155, Indonesia \\ ${ }^{3}$ Biochemistry Department, Faculty of Medicine, Universitas Sumatera Utara, Jl. Dr. Mansyur No.5, Medan 20155, Indonesia \\ ${ }^{4}$ Parasitology Department, Faculty of Medicine, Universitas Sumatera Utara, Jl. Dr. Mansyur No.5, Medan 20155, Indonesia \\ *Corresponding author. E-mail: dina@usu.ac.id
}

Received date: Oct 11, 2021; Revised date: Nov 15, 2021; Accepted date: Nov 17, 2021

\section{Abstract}

$\mathrm{B}$ ACKGROUND: The presence of vitamin D receptor (VDR) polymorphism and high levels of inflammatory markers are predisposing factors indicating disease progression and malnutrition. To meet nutritional needs in maintaining nutritional status in tuberculosis patients with VDR gene polymorphisms (TaqI or FokI), food that is easily absorbed and high in vitamin D, calcium, and protein is needed. This study was conducted to determine whether high vitamin $\mathrm{D}$ and calcium porridge called soy-catfish-anchovy-rice (SCAR) porridge would increase 25(OH)D serum levels and other parameters, including calcium, albumin, high-sensivity C-reactive protein (hs-CRP), and blood glucose serum levels.

METHODS: The study was a parallel, open, clinical trial. There were 22 subjects in the intervention (I) group who received $50 \mathrm{~g}$ of SCAR porridge once per day along with dietary counseling, and 21 subjects in the control (C) group who only received dietary counseling. All subjects with TC and CC (TaqI) or TC and CC (FokI) genotype were included in this study. The intervention lasted for 14 days, and the parameters such as $25(\mathrm{OH}) \mathrm{D}$, calcium, albumin, hs-CRP, and blood glucose serum levels were assessed before and after intervention between groups.

RESULTS: All subjects in both groups completed the study. After 14 days of intervention, there was a significant increase in 25(OH)D $(p=0.01)$ and decrease in hs-CRP ( $p=0.02$ ) serum levels in the I group, and no change was observed in the $\mathrm{C}$ group. There was no significant difference in albumin and blood glucose serum levels.

CONCLUSION: The results show that $50 \mathrm{~g}$ of SCAR porridge per day for 14 days is an effective supplementation that can increase 25(OH)D and decrease hs-CRP serum levels in tuberculosis patients with VDR gene polymorphism.

KEYWORDS: vitamin D, hs-CRP, polymorphism, porridge

Indones Biomed J. 2021; 13(4): 418-25

\section{Introduction}

Tuberculosis (TB) is a major global health problem, with prevalence rising each year, and is one of the main causes of mortality in Indonesia. Governments of various countries with the highest prevalence have implemented the directly observed treatment short-course (DOTS) and Stop TB strategies; however, new cases continually appear and relapse due to emerging resistance.(1) This condition is worsened by factors (e.g., environmental, nutritional, and genetic) that increase a person's susceptibility to Mycobacterium tuberculosis infection.(2-4) Previous studies showed that vitamin D receptor gene polymorphism significantly increases the risk of tuberculosis disease and comorbidities such as diabetes mellitus or human immunodeficiency virus (HIV)/acquired immunodeficiency syndrome (AIDS).(2) 
Vitamin D receptor gene polymorphism is related to both vitamin $\mathrm{D}$ deficiency and an increased risk of tuberculosis disease. Related genes, such as FokI and TaqI, are associated with low levels of vitamin D and play a role in immune regulation in the body. $(2,4,5)$ Vitamin D supports the induction of pleiotropic antimicrobial response in tuberculosis patients.(6,7) Vitamin D supplements may accelerate sputum conversion and help to improve the clinical condition of tuberculosis patients. Vitamin $\mathrm{D}$ promotes an increase in immune cells by activating the 25-hydroxyvitamin D receptor.(7,8) Food sources that contain high levels of vitamin $\mathrm{D}$, such as catfish and mushrooms, could be used as a natural supplementation to address low vitamin D levels. Soy, catfish, anchovy, and rice are food sources that contain high levels of calcium, vitamin $\mathrm{D}$, protein, and carbohydrates. Consuming these ingredients as a porridge could increase vitamin $\mathrm{D}$ and calcium levels in the blood.

Vitamin D deficiency is common in tropical areas such as Indonesia, occurring even in healthy individuals despite an abundance of sunlight hours. A sun-evading lifestyle, in addition to a lack of vitamin D intake, increases the prevalence of vitamin D deficiency. Vitamin D deficiency may impact calcium levels, although various studies have stated that this is not the case. Calcium plays a role in regulating tuberculosis infection via cellular activity.

Vitamin D modulates the body's immune response by increasing vitamin D receptor (VDR) activity and activating monocytes. $(7,9,10)$ Another mechanism is the active form of vitamin $\mathrm{D}, 1,25(\mathrm{OH})_{2} \mathrm{D}_{3}$, which hinders the proliferation of $\mathrm{T}$ cells and increases the abilities of pathogen-activated macrophages. $(10,11)$

VDR is a member of the nuclear receptor of transcription factors. VDR, along with the activation of $1.25(\mathrm{OH})_{2} \mathrm{D}_{3}$, binds the DNA response element and forms a heterodimer with the retinoic acid receptor (RXR). This heterodimer links vitamin D and vitamin A or carotenoids, including beta carotene. Previous research showed that polymorphisms of the VDR gene could result in low vitamin D levels; on the basis of these results, we used VDR gene polymorphisms here as inclusion criteria. $(2,12)$

To meet nutritional needs and maintain nutritional status in tuberculosis patients, it is necessary to eat foods that are easily absorbed and high in nutrients, namely, vitamin $\mathrm{D}$, calcium, and protein. So, we performed a randomized clinical trial to study the impact of soy-catfish-anchovy-rice (SCAR) porridge for 14 days on new patients diagnosed with both tuberculosis and associated complications. We tested the levels of $25(\mathrm{OH}) \mathrm{D}$, calcium, albumin, high- sensivity C-reactive protein (hs-CRP), and blood glucose serum levels before and after intervention.

\section{Methods}

\section{Study Design}

The study was a parallel, open, clinical trial with randomization; a total of 43 subjects with the VDR gene polymorphisms were selected. The study was performed from May to September 2019, recruited from two public health centers, the Teladan and Amplas public health centers, located in Medan, North Sumatra, Indonesia.

There were 22 subjects in the intervention (I) group who received $50 \mathrm{~g}$ of SCAR porridge once per day along with dietary counseling, and 21 subjects in the control (C) group who only received dietary counseling. Research subjects were men or women who met the inclusion criteria, chosen through a purposive sampling technique. The inclusion criteria were subject aged 18-60 years old, newly diagnosed with lung tuberculosis using interferon gamma release assay (IGRA) methods, found polymorphisms in VDR genes TaqI and FokI with a heterozygote genotype test performed on one of the TaqI and FokI genes, and being willing to participate in the study and having provided informed consent.

The exclusion criteria were being pregnant and/or a breastfeeding mother, failing to consume the porridge for more than 7 days, and experiencing a worsening of their clinical condition. In this study, all participants who had been randomized were included in statistical analysis and analyzed according to the group in which they were originally assigned regardless of which intervention they had received.

This research was registered on ClinicalTrials. gov Protocol Registration and Results System with ClinicalTrials.gov identifier NCT04613258. This study was conducted after ethical approval was obtained from the Health Research Ethics Committee of Sumatra Utara University Medical School (No. 135/TGL/KEPK FK USURSUP HAM/2019), and all participants provided written informed consent for the study procedure.

\section{Randomization Process}

Sample size was determined using a formula based on tuberculosis prevalence in Medan. To avoid bias in the study, this was a double-blind trial. Randomization was performed through block randomization. To further remove selection bias, the names of the research subjects were 
assigned codes. A block randomization process was then performed using a block table, which was divided using the closed-envelope method to divide I and $\mathrm{C}$ groups.

\section{Intervention}

The I group was given SCAR porridge supplementation in the form of a soft porridge (a mixture of $50 \mathrm{~g}$ dry powder porridge added to $200 \mathrm{~mL}$ of hot water) along with nutritional counseling. The $\mathrm{C}$ group only received nutritional counseling and no SCAR porridge supplementation. A 50 $\mathrm{g}$ portion of SCAR porridge was provided once a day for 14 days. SCAR porridge based on $100 \mathrm{~g}$ of the dry product contained $60 \mathrm{~g}$ of soy powder, $10 \mathrm{~g}$ of catfish powder, $5 \mathrm{~g}$ of anchovy powder, and $25 \mathrm{~g}$ of rice powder, and all of which contained high levels of vitamin D and calcium (Table 1).

The SCAR porridge was monitored and administered by a researcher once a week to inquire about adherence to supplementation consumption and perceived side effects. All research subjects went through a clearance period of one week and were requested not to consume any supplements. Afterwards, measurements were recorded before and after intervention, including tests for $25(\mathrm{OH}) \mathrm{D}$, calcium, albumin, hs-CRP, and blood glucose serum levels.

\section{Analysis of Single-Nucleotide Polymorphisms in VDR Gene}

Detection of single-nucleotide polymorphisms (SNPs) in the VDR gene as the inclusion criteria was performed in three steps: (1) DNA isolation through the salting-out

Table 1. Nutrition facts of soy, catfish, anchovy, and rice (SCAR) porridge.

\begin{tabular}{lc}
\hline \multicolumn{1}{c}{ Nutrient per $\mathbf{1 0 0}$ grams } & Nutrient Analysis \\
\hline Total calories & $396.60 \mathrm{Kcal} / 100 \mathrm{~g}$ \\
Carbohydrates & $62.49 \%$ \\
Protein & $18.12 \%$ \\
Total fat & $8.24 \%$ \\
Saturated fatty acids & $1.64 \%$ \\
Monounsaturated fatty acids & $2.12 \%$ \\
Polyunsaturated fatty acids & $4.48 \%$ \\
Sugar & $5.62 \%$ \\
Fiber & $7.72 \%$ \\
Vitamin D & $137.02 \mathrm{mcg} / 100 \mathrm{~g}$ \\
Calcium & $367.32 \mathrm{mg} / 100 \mathrm{~g}$ \\
Natrium & $180.35 \mathrm{mg} / 100 \mathrm{~g}$ \\
Kalium & $366.84 \mathrm{mg} / 100 \mathrm{~g}$ \\
Vitamin E & $0.89 \mathrm{mg} / 100 \mathrm{~g}$ \\
Vitamin A & $13.84 \mathrm{mcg} / 100 \mathrm{~g}$ \\
Vitamin B6 & $10.35 \mathrm{mg} / 100 \mathrm{~g}$ \\
Cholesterol & $10.35 \mathrm{mg} / 100 \mathrm{~g}$ \\
\hline
\end{tabular}

method, (2) DNA purity validation, and (3) SNP genotyping using Applied Biosystem StepOnePlusTM Real-Time PCR Real-Time PCR System (Applied Biosystems, Foster City, CA, USA). Single-nucleotide polymorphism genotyping was initiated using 1-10 ng of DNA. Both VDR gene polymorphisms, TaqI and FokI, were tested by allele discrimination using a StepOnePlusTM Real-Time PCR instrument (Applied Biosystems). TaqMan probes were also obtained from Applied Biosystems. PCR was run on Fast mode. The protocol began with the activation of DNA polymerase at $95^{\circ} \mathrm{C}$ for 20 seconds, followed by denaturation at $95^{\circ} \mathrm{C}$ for 3 seconds and annealing at $60^{\circ} \mathrm{C}$ for 30 seconds. The process comprised 40 cycles. Strand fluorescence was detected at $60^{\circ} \mathrm{C}$. The assay was performed for a $10 \mu \mathrm{L}$ reaction solution using TaqMan genotyping Master Mix and 96-well reaction plates. A MicroAmp Fast Optical 96-well reaction plate covered with MicroAmp Optical Adhesive Film was obtained from Applied Biosystem. Three genotypes were found in each VDR gene, namely, TT, TC, and CC, and the subject with the TC and CC (TaqI) or TC and CC (FokI) genotype was included in this study.

\section{Laboratory Examinations for Vitamin D, Calcium, Albumin, hs-CRP, and Blood Glucose}

At the end of the study, samples were stored at $-80^{\circ} \mathrm{C}$, and the sample data were analyzed. Laboratory examiners did not know which specimens were case or control samples, as samples were randomly assigned codes. The $25(\mathrm{OH})$ D serum level was measured using a chemiluminescent immunoassay (CLIA) (Diasorin, Stillwater, MN, USA) device, and measurement range was between 4.0 and 150 $\mathrm{ng} / \mathrm{mL}$. The lowest level was $4.0 \mathrm{ng} / \mathrm{mL}$ based on interassay precision of $3.90 \% \mathrm{CV}$. Vitamin D levels were categorized as: $<20 \mathrm{ng} / \mathrm{mL}$, deficiency; $20-30 \mathrm{ng} / \mathrm{mL}$, insufficiency; and 30-100 $\mathrm{ng} / \mathrm{mL}$, sufficiency.(13) Serum calcium levels were measured using the ADVIA Bayer Assayed Chemistry Controls with a reaction measurement of $545 / 658 \mathrm{~nm}$; normal calcium serum levels were considered to be $8.3-10.6$ $\mathrm{mg} / \mathrm{dL}$. Albumin levels were measured using an Architect c8000; normal albumin serum levels were considered to be 3.4-4.8 g/dL. Hs CRP levels were measured using an Immulite 2000; normal Hs CRP serum levels were considered to be less than $10 \mathrm{mg} / \mathrm{dL}$. Blood glucose was measured using an Architect c8000; normal blood glucose serum levels were considered to be less than $140 \mathrm{mg} / \mathrm{dL}$.

\section{Data Analysis}

Continuous variables were expressed as continuous variables using means \pm SD. Differences in all parameters between 
the two groups were established by using an independent $\mathrm{t}$-test. Differences before and after the intervention in each group were analyzed using a dependent t-test. Categorical variables were expressed as percentage proportions; to show the relationships between vitamin D deficiency in the two groups, a chi-squared test was used, and the Fischer test if the data did not meet the criteria. A $p$-value of $<0.05$ was considered to be statistically significant. We used the SPSS program (version 11.5; SPSS Inc, Chicago, IL, USA) to perform analysis.

\section{Results}

This study consisted of 43 research subjects after completing the screening process through inclusion and exclusion criteria from a total of 57 research subjects. All subjects with a TC or CC genotype (TaqI) or TC or CC genotype (FokI) were included in this research, and 14 subjects were excluded. After signing an informed consent form and undergoing block randomization, they were divided into two groups, The I group (22 research subjects) and C group (21 research subjects) groups. During the study period, one research subject could not participate until the end of the period because they had experienced nausea and did not routinely consume the porridge, and one research subject had problems but still participated in having their blood drawn at the end of the study as part of the research as an intention-to-treat method.

\section{Baseline Characteristics}

The baseline characteristics of all research subjects showed that most tuberculosis prevalence was experienced by those who were younger, married, male, and with normal body weight (Table 2). Statistical testing did not show any differences between the groups, and did not indicate any significant differences between the $\mathrm{I}$ and $\mathrm{C}$ groups. For baseline characteristics, both groups were homogeneous.

\section{Categories and Laboratory Parameter Levels}

For the I group, vitamin D levels were the most significantly increased of all nutrients. There was no significant difference between before and after nutrient intake in the $\mathrm{C}$ group (Table 3). Before the study, vitamin D deficiency and insufficiency percentages were in higher numbers in all research subjects. In the I group, seven subjects were categorized in deficiency $(16.3 \%)$, nine subjects were categorized in insufficiency (20.9\%), and six subjects were categorized in sufficiency (14.0\%). In the control group, six subjects were
Table 2. Demographic characteristics of all subjects.

\begin{tabular}{|c|c|c|}
\hline Characteristic & $\begin{array}{c}n(\%) \\
(n=43)\end{array}$ & Mean \pm SD \\
\hline Age (year) & & $41.4 \pm 16.1$ \\
\hline $20-29$ & $18(40.9)$ & \\
\hline $30-39$ & $4(11.4)$ & \\
\hline $40-49$ & $8(18.2)$ & \\
\hline $50-59$ & $6(13.6)$ & \\
\hline$\geq 60$ & $7(15.9)$ & \\
\hline \multicolumn{3}{|l|}{ Gender } \\
\hline Female & $20(46.5)$ & \\
\hline Male & $23(53.5)$ & \\
\hline BMI $\left(\mathrm{kg} / \mathrm{m}^{2}\right)$ & & $21.0 \pm 3.9$ \\
\hline \multicolumn{3}{|l|}{ BMI categorized } \\
\hline Underweight & $10(22.7)$ & \\
\hline Normal & $22(50.0)$ & \\
\hline Overweight & $1(4.5)$ & \\
\hline Obese 1 & $8(18.2)$ & \\
\hline Obese 2 & $2(4.5)$ & \\
\hline \multicolumn{3}{|l|}{ Marital status } \\
\hline Married & $26(59.1)$ & \\
\hline Single & $17(40.9)$ & \\
\hline \multicolumn{3}{|l|}{ Occupation } \\
\hline Employeed & $22(50.0)$ & \\
\hline Businessman & $9(20.5)$ & \\
\hline Housewife & $4(9.1)$ & \\
\hline Unemployed & $1(4.5)$ & \\
\hline Student & $7(15.9)$ & \\
\hline \multicolumn{3}{|l|}{ Smoking status } \\
\hline Smokers & $24(54.5)$ & \\
\hline Non-smokers & $19(45.5)$ & \\
\hline \multicolumn{3}{|l|}{ Sunlight exposure } \\
\hline$<30$ minutes & $25(58.1)$ & \\
\hline$\geq 30$ minutes & $18(41.9)$ & \\
\hline \multicolumn{3}{|l|}{ Physical activity } \\
\hline High & - & \\
\hline Moderate & - & \\
\hline Low & $32(72.7)$ & \\
\hline Medium & $11(27.3)$ & \\
\hline \multicolumn{3}{|l|}{ Scar BCG } \\
\hline Clear & $32(72.7)$ & \\
\hline Dubious & $5(13.6)$ & \\
\hline None & $6(13.6)$ & \\
\hline
\end{tabular}

categorized in deficiency (14\%), ten subjects categorized in insufficiency $(23.3 \%)$, and five subjects categorized in sufficiency $(11.6 \%)$. No research subjects were categorized as normal; the highest levels were categorized as sufficient, and there was no significant difference between the two groups before intervention. However, when data collected before the study were compared, vitamin D and calcium levels were homogeneous. After the study, in the I group, four subjects were categorized in deficiency $(9.3 \%)$, eleven subjects categorized in insufficiency (25.6\%), and seven subjects categorized in sufficiency (16.3\%). In the C group, eight subjects were categorized in insufficiency $(18.6 \%)$, and thirteen subjects categorized in sufficiency $(30,2 \%)$; 
Table 3. Energy and nutrient intake of subjects before and after intervention period.

\begin{tabular}{lcccccc}
\hline \multirow{2}{*}{ Nutrient Intake } & \multicolumn{3}{c}{ Intervention Group $(\mathbf{n = 2 2})$} & \multicolumn{3}{c}{ Control Group (n=21) } \\
\cline { 2 - 6 } & Before & After & $\boldsymbol{p}$-value & Before & After & p-value \\
\hline Energy $(\mathrm{kcal})$ & $702.1 \pm 73.4$ & $751.9 \pm 85.4$ & 0.25 & $768.1 \pm 76.2$ & $726.8 \pm 69.7$ & 0.63 \\
Protein $(\mathrm{g})$ & $22.4 \pm 5.6$ & $27.2 \pm 8.3$ & 0.10 & $25.1 \pm 6.8$ & $24.5 \pm 9.7$ & 0.85 \\
Fat $(\mathrm{g})$ & $19.1 \pm 3.2$ & $20.5 \pm 6.7$ & 0.61 & $18.8 \pm 5.7$ & $18.3 \pm 5.4$ & 0.85 \\
Carbohydrate $(\mathrm{g})$ & $110.2 \pm 34.7$ & $115.9 \pm 23.5$ & 0.39 & $124.5 \pm 54.3$ & $116.1 \pm 55.6$ & 0.55 \\
Cholesterol $(\mathrm{mg})$ & $95.1 \pm 15.6$ & $139.3 \pm 21.1$ & 0.22 & $83.9 \pm 14.3$ & $83.8 \pm 18.5$ & 0.99 \\
Fiber $(\mathrm{g})$ & $5.2 \pm 1.2$ & $6.8 \pm 1.4$ & 0.03 & $4.9 \pm 2.3$ & $4.8 \pm 1.6$ & 0.94 \\
Vitamin A $(\mu \mathrm{g})$ & $485.9 \pm 155.8$ & $769.2 \pm 212.2$ & 0.07 & $582.6 \pm 221.2$ & $448.8 \pm 201.4$ & 0.44 \\
Carotene $(\mathrm{mg})$ & $0.1 \pm 0.01$ & $0.1 \pm 0.02$ & 0.55 & $1.2 \pm 0.4$ & $0.1 \pm 0.04$ & 0.17 \\
Calcium $(\mathrm{mg})$ & $229.1 \pm 78.3$ & $195.4 \pm 55.2$ & 0.47 & $272.4 \pm 65.4$ & $181.5 \pm 66.7$ & 0.14 \\
Vitamin D $(\mu \mathrm{g})$ & $3.4 \pm 0.6$ & $30.2 \pm 8.7$ & $0.01 *$ & $3.6 \pm 0.8$ & $2.9 \pm 1.1$ & 0.12 \\
\hline
\end{tabular}

Data are shown in mean \pm SD. *Significance value: $p<0.05$, analysis using dependent t-test.

$p=0.44$. There were significantly differences between the two groups.

There were no differences in the categorization of calcium serum level, albumin, Hs-CRP, and blood glucose between the two groups. Calcium categorization before and after intervention showed no significant differences, and all subjects in the two groups had normal calcium levels (normal range $8.3-10.6 \mathrm{mg} / \mathrm{dL}$ ).

There were two subjects $(4.7 \%)$ in the $\mathrm{C}$ group and three subjects (7\%) in I group with low albumin level. After intervention, there were no subjects with low albumin level, and there was high calcium categorization in the I group (19 subjects; 44.2\%) and C group (17 subjects; 39.5\%) groups after intervention, but there were no significant differences between two groups after intervention.

Before intervention, there were 12 subjects $(27.9 \%)$ categorized as having higher hs-CRP level; after intervention, there were 9 subjects $(20.9 \%)$ categorized as having higher hs-CRP level. So, there was a decrease in hs-CRP level in the I group. In the $\mathrm{C}$ group, there was an increase in the subject's hs-CRP level before and after intervention (9 to 10 subjects). However, there were no significant differences between the two groups in hs-CRP level before and after intervention. This research also showed there was no difference between blood glucose categorization between the two group before and after intervention.

There was also no numerical difference between two groups except for laboratory parameter vitamin D levels, in which we observed significant difference when compared to data that had been collected before the study commenced. This indicated that laboratory parameter levels increased, though they were still below normal values (Table 4). Table 4 shows that, before intervention, data were homogeneous for $25(\mathrm{OH}) \mathrm{D}$, calcium, albumin, hs-CRP, and blood glucose serum levels. There were significant differences between both groups in $25(\mathrm{OH}) \mathrm{D}$ serum levels; the average $25(\mathrm{OH})$ D serum level was low in the I group, but high in the $\mathrm{C}$ group.

\section{Discussion}

Polymorphisms of the VDR gene influence 25(OH)D serum levels in the body. Two widely studied VDR genes are TaqI and FokI, especially concerning tuberculosis. We included VDR gene polymorphism testing for all research subjects, searching for the heterozygote genotypes on the VDR gene, namely, TaqI (rs731236) or FokI (rs10735810). SCAR porridge supplementation, providing all necessary vitamins and minerals, especially vitamin D and calcium, could result in improving the clinical condition of tuberculosis patients experiencing complications. In previous studies, FokI receptor gene polymorphism was related to an increased risk of tuberculosis. $(5,14)$ This study showed that patients with VDR gene polymorphisms exhibit vitamin $D$ deficiency and insufficiency. The administration of SCAR porridge increased vitamin D levels, but still did not significantly increase other vitamin and mineral serum levels compared to the control group. Vitamin D levels in the intervention group were significantly higher than those in the control group; therefore, the administration of vitamin D supplementation is highly necessary for tuberculosis patients with VDR gene polymorphisms. At the end of this study, a significant improvement in sputum conversion was observed.

Other factors to be considered were body fat mass and profession. In this study, patients mostly had low levels of body fat. Although a high level of fat was found 
Table 4. Vitamin D, calcium, albumin, hs-CRP, and blood glucose serum levels before and after intervention.

\begin{tabular}{|c|c|c|c|}
\hline \multirow[b]{2}{*}{ Variable } & \multicolumn{2}{|c|}{ Mean \pm SD } & \multirow[b]{2}{*}{$p$-value } \\
\hline & $\begin{array}{r}\text { Baseline } \\
\text { (Day 0) }\end{array}$ & $\begin{array}{l}\text { Endpoint } \\
\text { (Day 14) }\end{array}$ & \\
\hline \multicolumn{4}{|l|}{$25(\mathrm{OH}) \mathrm{I}$ serum $(\mathrm{ng} / \mathrm{mL})$} \\
\hline I group $(n=22)$ & $24.6 \pm 9.4$ & $32.5 \pm 5.9$ & $0.01 *$ \\
\hline C group $(n=22)$ & $25.6 \pm 9.7$ & $27.5 \pm 8.8$ & $0.01 *$ \\
\hline$p$-value & 0.74 & $0.03 * *$ & \\
\hline \multicolumn{4}{|l|}{ Calcium serum (mg/dL) } \\
\hline I group $(n=22)$ & $9.6 \pm 0.5$ & $9.8 \pm 0.7$ & 0.13 \\
\hline C group $(n=22)$ & $9.4 \pm 0.5$ & $9.6 \pm 0.8$ & 0.27 \\
\hline$p$-value & 0.17 & 0.05 & \\
\hline \multicolumn{4}{|l|}{ Albumin serum $(\mathrm{mg} / \mathrm{dL})$} \\
\hline I group $(\mathrm{n}=22)$ & $3.91 \pm 0.4$ & $3.86 \pm 0.3$ & 0.57 \\
\hline C group $(n=22)$ & $3.86 \pm 0.3$ & $3.81 \pm 0.4$ & 0.71 \\
\hline$p$-value & 0.09 & 0.54 & \\
\hline \multicolumn{4}{|l|}{ Hs CRP serum (mg/dL) } \\
\hline I group $(\mathrm{n}=22)$ & $24.0 \pm 7.7$ & $12.1 \pm 2.7$ & $0.02 *$ \\
\hline C group $(n=22)$ & $17.0 \pm 4.3$ & $11.0 \pm 9.4$ & 0.27 \\
\hline$p$-value & 0.21 & 0.32 & \\
\hline \multicolumn{4}{|c|}{ Blood Glucose serum (mg/dL) } \\
\hline I group $(n=22)$ & $184.6 \pm 88.7$ & $182 \pm 90.3$ & 0.93 \\
\hline C group $(n=22)$ & $139.05 \pm 28.1$ & $139.7 \pm 23.9$ & 0.93 \\
\hline$p$-value & 0.22 & 0.15 & \\
\hline
\end{tabular}

Data are shown in mean \pm SD. ${ }^{*}$ Significance value: $p<0.05$. The independent t-test analysis was used to see the differences between the two groups, while the dependent t-test analysis was used to see the differences before and after treatment in each group.

in some patients, vitamin D levels were still categorized as either deficient or insufficient. Low vitamin D levels at the start of the study were probably caused by VDR gene polymorphisms, aside from other possibilities such as disease progression, a sun-evading lifestyle, and a lack of high vitamin D and calcium intake.(15-18) A patient's profession also affected vitamin D levels. Professions that involve less sunlight (e.g., indoor jobs) cause more pronounced vitamin D deficiency.(19-22)

We did not find any relationship between calcium and vitamin D. Calcium intake also did not increase in this study. Dietary sources of calcium such as milk, sour milk, or cheese are food products that are not commonly part of daily meals for tuberculosis patients. This lack of calcium may be caused by the lack of consumption of such products by tuberculosis patients. This may be caused by the high prices of food or milk not being a commonly consumed food product. Other calcium food sources include fish consumed along with their bones, such as anchovies. $(23,24)$ This is a kind of food product that may be provided to tuberculosis patients to fulfill calcium requirements.
We did not find low serum calcium levels in the blood even though the mean of 25(OH)D serum levels was low. In tuberculosis patients, low levels of $25(\mathrm{OH}) \mathrm{D}$ were found, which should have an interaction between vitamin $\mathrm{D}$ and calcium. If the level of vitamin D in the blood is high, calcium absorption increases; however, this mechanism did not occur in this study. Although 1000 IU of vitamin D was administered per day for 28 days, and vitamin D levels increased (though not enough for any patient to be categorized as sufficient), this did not affect calcium levels in the blood. Calcium plays a vital role in bone remodeling and is supported by vitamin $\mathrm{D}$, which is converted into calcitriol and helps in the absorption of calcium in the intestine.

About $300-500 \mathrm{mg}$ of calcium is sourced from 900 $\mathrm{mg}$ of extracellular calcium to aid in the process of bone remodeling. This increases the required calcium intake from food sources, so calcium intake requirements range from 1000 to $1500 \mathrm{mg}$.(25-27) This puts serum calcium into a homeostatic (balanced) state. Phosphorus also plays a role in balancing calcium levels in the blood and the rate of calcium storage in the intestine. The process of calcium 
absorption with the support of vitamin D is significant for the metabolism of calcium and phosphorus.(28) Calcium absorption by the digestive tract increases as calcium and phosphorus from the bone mobilize, and vitamin D controls the expenditure and balance of minerals in the blood.(27) Although calcium and vitamin D metabolism appear to be altered in tuberculosis patients, we found no association between vitamin $\mathrm{D}$ and calcium categorization in this study. Previous studies confirmed that, although serum calcium is raised in tuberculosis patients, the effect may be reduced by a low calcium intake.(29)

During this study, the administration of vitamin D with nutritional counseling, including a high intake of $\beta$ carotene food, showed improved sputum conversion in both groups. A significant increase in vitamin D levels, despite the lack of difference between the intervention and control groups observed at the end of this study, still showed clinical improvement in tuberculosis patients.

This study showed that the supplementation of SCAR porridge resulted in a significant increase in the intervention group compared to the control group, although other factors resulted in no research subjects in the normal vitamin D category. This may have been caused by VDR gene polymorphisms. This study has several limitations, for example, not measuring parathyroid hormone levels and other clinical parameters of tuberculosis improvement, such as chest X-ray and blood inflammation parameters. The limitations of this study can be covered by the results of the examination of serum $25(\mathrm{OH}) \mathrm{D}$ in research subjects supported by other examinations, so that the results of this study show evidence that describes the effect of supplementation on the cellular level.

\section{Conclusion}

The results show that $50 \mathrm{~g}$ of SCAR porridge per day for 14 days is an effective supplementation that can increase 25(OH)D and decrease Hs CRP serum levels in tuberculosis patients with VDR gene polymorphism.

\section{Acknowledgements}

The authors gratefully acknowledge that the present research was supported by the Ministry of Research and Technology and the Higher Education Republic of Indonesia, Research and Community Service, Universitas
Sumatra Utara. The support is under research grant DRPM KEMENRISTEKDIKTI, 2019, contract number: 11/UN5.2.3.1/PPM/KP-DRPM/2019. Patent number certificate: S00201900847.

The authors would like to thank all research subjects, the Head of the Health Office of the City of Medan, Heads of the Public Health Centers of Teladan, Drs. Kus Puji Astuti and Amplas, Dr. Henni Safitri, the medical-paramedical team, and the students who supported this research. The authors also would like to thank Prodia Laboratory Medan for providing the supportive laboratory examination in this research.

\section{Authors Contribution}

DKS were involved in the research conception and manuscript preparation; DKS and RD coordinated the study; RD and DMD analyzed the data and interpreted the results; MIS and DKS performed data acquisition; and MIS was responsible for the table design and laboratory analysis. All authors participated in the critical revision of the manuscript.

\section{References}

1. Areeshi MY, Mandal RK, Dar SA, Alshahrani AM, Ahmad A, Jawed $\mathrm{A}$, et al. A reappraised meta-analysis of the genetic association between vitamin D receptor BsmI (rs1544410) polymorphism and pulmonary tuberculosis risk. Biosci Rep. 2017; 37: BSR20170247. doi: 10.1042/BSR20170247.

2. Huang L, Liu C, Liao G, Yang X, Tang X, Chen J. Vitamin D receptor gene FokI polymorphism contributes to increasing the risk of tuberculosis: an update meta-analysis. Medicine (Baltimore). 2015; 94: e2256. doi: 10.1097/MD.0000000000002256.

3. Areeshi MY, Mandal RK, Wahid M, Dar SA, Jawed A, Lohani M, et al. Vitamin D receptor ApaI (rs7975232) polymorphism confers decreased risk of pulmonary tuberculosis in overall and African population, but not in Asians: evidence from a meta-analysis. Ann Clin Lab Sci. 2017; 47: 628-37.

4. Andraos C, Koorsen G, Knight JC, Bornman L. Vitamin D receptor gene methylation is associated with ethnicity, tuberculosis, and TaqI polymorphism. Hum Immunol. 2011; 72: 262-8.

5. Harishankar M, Selvaraj P. Regulatory role of $\mathrm{Cdx}-2$ and Taq I polymorphism of vitamin D receptor gene on chemokine expression in pulmonary tuberculosis. Hum Immunol. 2016; 77: 498-505.

6. Wu YJ, Yang X, Wang XX, Qiu MT, You YZ, Zhang ZX, et al. Association of vitamin D receptor BsmI gene polymorphism with risk of tuberculosis: a meta-analysis of 15 studies. PLoS One. 2013; 8: e66944. doi: 10.1371/journal.pone.0066944.

7. Cervantes JL, Oak E, Garcia J, Liu H, Lorenzini PA, Batra D, et al. Vitamin $\mathrm{D}$ modulates human macrophage response to Mycobacterium tuberculosis DNA. Tuberculosis (Edinb). 2019; 116S: S131-7. 
8. Hong Y, Kim Y, Lee JJ, Lee MG, Lee CY, Kim Y, et al. Levels of vitamin D-associated cytokines distinguish between active and latent tuberculosis following a tuberculosis outbreak. BMC Infect Dis. 2019; 19: 151. doi: 10.1186/s12879-019-3798-5.

9. Tessema B, Moges F, Habte D, Hiruy N, Yismaw S, Melkieneh $\mathrm{K}$, et al. Vitamin D deficiency among smear positive pulmonary tuberculosis patients and their tuberculosis negative household contacts in Northwest Ethiopia: a case-control study. Ann Clin Microbiol Antimicrob. 2017; 16: 36. doi: 10.1186/s12941-0170211-3.

10. Fiske CT, Blackman A, Maruri F, Rebeiro PF, Huaman M, Kator J, et al. Increased vitamin $\mathrm{D}$ receptor expression from macrophages after stimulation with $\mathrm{M}$. tuberculosis among persons who have recovered from extrapulmonary tuberculosis. BMC Infect Dis. 2019; 19: 366. doi: 10.1186/s12879-019-3958-7.

11. Bishwal SC, Das MK, Badireddy VK, Dabral D, Das A, Mahapatra $\mathrm{AR}$, et al. Sputum proteomics reveals a shift in vitamin D-binding protein and antimicrobial protein axis in tuberculosis patients. Sci Rep. 2019; 9(1): 1036. doi: 10.1038/s41598-018-37662-9.

12. Magee MJ, Sun YV, Brust JCM, Shah NS, Ning Y, Allana S, et al. Polymorphisms in the vitamin D receptor gene are associated with reduced rate of sputum culture conversion in multidrug-resistant tuberculosis patients in South Africa. PLoS One. 2017; 12(7): e0180916. doi: 10.1371/journal.pone.0180916.

13. Holick MF. The vitamin D deficiency pandemic: Approaches for diagnosis, treatment and prevention. Rev Endocr Metab Disord. 2017; 18: 153-65.

14. Zhao ZZ, Zhang TZ, Gao YM, Feng FM. Meta-analysis of relationship of vitamin $\mathrm{D}$ receptor gene polymorphism and tuberculosis susceptibility. Zhonghua Jie He He Hu Xi Za Zhi. 2009; 32: 748-51.

15. Balcells ME, Garcia P, Tiznado C, Villarroel L, Scioscia N, Carvajal $\mathrm{C}$, et al. Association of vitamin D deficiency, season of the year, and latent tuberculosis infection among household contacts. PLoS One. 2017; 12(4): e0175400. doi: 10.1371/journal.pone. 0175400.

16. Grober U, Reichrath J, Holick MF. Live longer with vitamin D? Nutrients. 2015; 7: 1871-80.

17. Aibana O, Franke MF, Huang CC, Galea JT, Calderon R, Zhang Z, et al. Impact of vitamin A and carotenoids on the risk of tuberculosis progression. Clin Infect Dis. 2017; 65: 900-9.
18. Sari DK, Mega JY, Harahap J. Nutrition status related to clinical improvement in AFB-positive pulmonary tuberculosis patients in primary health centres in Medan, Indonesia. Open Access Maced J Med Sci. 2019; 7: 1621-7.

19. Holick MF. Bioavailability of vitamin D and its metabolites in black and white adults. N Engl J Med. 2013; 369: 2047-8.

20. Holick MF, Chen TC, Lu Z, Sauter E. Vitamin D and skin physiology: a D-lightful story. J Bone Miner Res. 2007; 22 (Suppl 2): V28-33.

21. Maceda EB, Goncalves CCM, Andrews JR, Ko AI, Yeckel CW, Croda J. Serum vitamin D levels and risk of prevalent tuberculosis, incident tuberculosis and tuberculin skin test conversion among prisoners. Sci Rep. 2018; 8: 997. doi: 10.1038/ s41598-018-19589-3.

22. McCullough PJ, Lehrer DS. Vitamin D, cod liver oil, sunshine, and phototherapy: Safe, effective and forgotten tools for treating and curing tuberculosis infections - A comprehensive review. J Steroid Biochem Mol Biol. 2018; 177: 21-9.

23. Holick MF. Vitamin D: a D-Lightful health perspective. Nutr Rev. 2008; 66 (10 Suppl 2): S182-94.

24. Karaguzel G, Dilber B, Can G, Okten A, Deger O, Holick MF. Seasonal vitamin D status of healthy schoolchildren and predictors of low vitamin D status. J Pediatr Gastroenterol Nutr. 2014; 58: 65460 .

25. Suzuki A. Body weight and bone/calcium metabolism. Treatment of osteoporosis with diabetes. Clin Calcium. 2018; 28: 957-61.

26. Yamaguchi T, Saiki A, Tatsuno I. Body weight and bone/calcium metabolism. Response of bone metabolism after bariatric surgery. Clin Calcium. 2018; 28: 973-8.

27. Li P, Chang X, Fan X, Fan C, Tang T, Wang R, et al. Dietary calcium status during maternal pregnancy and lactation affects lipid metabolism in mouse offspring. Sci Rep. 2018; 8: 16542. doi: 10.1038/s41598-018-34520-6.

28. Jassil NK, Sharma A, Bikle D, Wang X. Vitamin D binding protein and 25-hydroxyvitamin D levels: emerging clinical applications. Endocr Pract. 2017; 23: 605-13.

29. Rohini K, Bhat S, Srikumar PS, Mahesh Kumar A. Assessment of serum calcium and phosphorus in pulmonary tuberculosis patients before, during and after chemotherapy. Indian $\mathrm{J}$ Clin Biochem. 2014; $29: 377-81$. 